\title{
Effect of Fuel wood on the Quality of Smoked Freshwater Fish Species Sold in Tamale Central Market, Northern Region, Ghana. 1Obodai, E.A., ${ }^{2}$ Muhammad, B.A. ${ }^{10 b o d a i, ~ G . A . ~ a n d ~}{ }^{3}$ Opoku, E.
}

\begin{abstract}
The study was conducted in Tamale and three villages around it. The method involved processing and smoking some raw freshwater fish species with different fuel wood species to ascertain the quality of the smoked products. A market survey was conducted to match the quality of the smoked products with those sold on the market and determine consumer preference on the Tamale Central Market (TCM). The results indicate that eight locally available fuel wood species produced preferred colours in the smoked fish; and have been classified as good fuel wood; while two imparted least preferred colours, and are considered bad fuel wood. All the fuel wood species had high relative efficiency (>5.5\%). Thirty-one smoked freshwater fish species, belonging to 21 families were sold on the TCM. These come from 9 sources. Yeji supplied the highest quantity. Smoked freshwater fish species make a significant contribution to the economy of the Tamale Metropolis.
\end{abstract}

\section{Introduction}

ish is an important source of cheap
first class protein, providing essential amino acids (Paul and Southgate, 1978). Fish is low in fat and cholesterol ,it is also rich in calcium, phosphorus, vitamins A and D (Osuji, 1976; Brigette et al., 1994). Fishes such as herrings, mackerel, sardine and tuna contain omega-3-fatty acids, which prevent heart disorders. According to Mayhew and Penny (1988), fish is quicker to cook and is more easily digested than meat of other animals. The results of a study conducted by Sipe (1993) have shown a positive correlation between the amounts of fish consumed and life span of the consumer. This author reported that majority of Americans and Japanese who depend on fish as their main source of protein therefore have longer life span.

In spite of the importance of fish and the fishing industry, fish is an extremely perishable commodity, spoiling soon after death, due to enzymatic and microbial actions, resulting in disagreeable taste, smell and texture; thereby reducing consumer acceptability Bribitte et al. 1994; Garrow and James, 1994). These authors asserted that high ambient temperatures of the tropics is a major environmental factor promoting rapid spoilage of fish. Maddison et al. (1993) suggested refrigeration as means of preventing the fast rate of deterioration in fish. They also cited careful handling and rapid processing as essential steps to overcome the problem of rapid fish spoilage.

Therefore, to maintain the freshness of fish, the catch must be stored in cold rooms until it is ready for processing. However, some bacteria (e.g. Salmonella), which survive in refrigerator and brine, can only be destroyed by heating (Bender, 1982).

Several fish processing methods include fermentation, drying, frying, canning, salting and smoking. Smoking, which is the main object of this paper, may be done in a variety of ways: pre-drying or salting before smoking; cold-smoking which involves the use of little fuel-wood that produces low heat and the products obtained do not keep long; and Hot-smoking which entails the application of much more heat, through the burning of large quantity of fuel-wood (Clucas, 1982). The products from hot-smoking are tastier (Osuji, 1976) and have longer shelf-lives (Maddison et al., 1993). Smoking preserves fish by drying, cooking and depositing natural wood-smoke chemicals like tars, phenols and aldehydes all of which have powerful bactericidal action and prevent the growth of other micro-organisms on the flesh of the fish (Garrow and James, 1994). The flavour of smoke lies in the quantity of the smoke that the flesh is coated with (Anazonwu-Bello, 1976). The smoke determines the colour, which is one of the qualities that attract consumers. The colour is largely dependent on the method as well as the type of fuel wood used in smoking the fish. The colour ranges from black, dark brown, golden brown or light brown to dirty white. Consumer preference of colour of smoked fish varies from place to place. For instance, in Southern Ghana consumers prefer golden brown-coloured smoked fish for immediate

1 Department of Fisheries and Aquatic Sciences, University of Cape Coast, Ghana obodai254@yahoo.com

${ }^{2}$.NGL NEWMONT, Box 59,Kenyanse, B/A, Ghana $\quad 3$. UDS, Tamale, N/R, Ghana 
use, but dark brown for storage or transport (per. Com. with Maku Adinortey, Fishmongers' Association, Duakor, Cape Coast). However, at Bontanga in the Northern Region of Ghana, consumers show varying degrees of preference for dark and light brown colours. The fishmongers use particular types of fuel wood to obtain the desirable colours. There are claims that other types of fuel wood impart undesirable colours (sooty or white). However, these claims have not been documented. Therefore the objectives of this study are to : determine the effects of different fuel wood species on the quality of smoked fish; assess the relative efficiency of ten fuel wood species; classify the ten fuel wood species into good and bad smoking fuel wood; identify the smoked freshwater fish sold on the Tamale Central Market (TCM) in Ghana; determine the sources of the smoked freshwater fish species; and assess the quantity of freshwater fish species on the TCM.

\section{Study Areas}

The study was conducted in Tamale and three villages around it. These villages are Bontanga, Golinga and Nyankpala, located 30 $\mathrm{km}$, (northwest), $12 \mathrm{~km}$ southwest and $16 \mathrm{~km}$ west of Tamale, respectively. The areas lie between latitudes $9^{0}$ and $10^{\circ} \mathrm{N}$, and longitudes $0^{0}$ and $2^{0} \mathrm{~W}$. Bontanga has a reservoir with a surface area of about 770 ha, while the dugout at Golinga covers approximately 192.5 ha. (Obodai and Kwofie, 2001).

\section{Methodology}

The required data were to identify and collect fuel wood species, assess their efficiency of smoking to produce the colour preferred by consumers and to classify the fuel wood species based on the colour they impart on the smoked products. The required information was obtained through primary and secondary data collection.

Locally available fuel wood species within the study areas were identified, harvested with cutlasses and dried for 2 months prior to the start of the experiments. Each fuel-wood species was tied into head-load bundles weighing $20 \mathrm{~kg}$ each (dry weight).

The efficiency of fuel wood species was done by using a known weight of the dry fuel wood (X), in smoking a given weight of fish, till a constant weight (K) was obtained. The left over fuel wood (fuel wood residue) was weighed (Y). The fuel wood performance (or relative efficiency) was then calculated by using the formula:

Fuel wood performance.

$$
(\mathrm{FWP})=\frac{\mathrm{K}}{\mathrm{X}-\mathrm{Y}} \times 100
$$

Consumer preference was obtained by administering questionnaire, which sought to find out the colour of smoked fish preferred by groups of consumers in the three study areas.

Classification of fuel wood into good or bad fuel wood was based on the colour it gave to the smoked fish. Good fuel wood species imparted golden brown or dark brown colour, either of which was desirable or acceptable to consumers; while the bad firewood species produced light brown colour (which consumers did not like) in the smoked product.

Smoked freshwater fish species sold on the (TCM) were identified using physical observation to get the local names and their botanical species name were identified through literature by Holden and Reed (1991) and Dankwa et al. (1999).

Sources of smoked freshwater fish species on the TCM was determined through administration of questionnaire to all the ten fishmongers in the TCM. This questionnaire sought to know where the smoked freshwater fish they (fishmongers) sell came from, among other things as well as the quantity of smoked freshwater fish species sold on the TCM during the lean and the bumper harvest seasons, for a period of one year. The interviews were conducted by the use of a semi-structured questionnaire.

The data collected were analyzed using simple descriptive statistics and presented in form of tables

\section{Results and Discussion}

This section of the paper focuses on effect of selected commonly used fuel-wood species on the quality of smoked freshwater fish species and the flow of these smoked products into the Tamale Central Market. The foregoing discussion of the results obtained is therefore confined to these aspects.

The fuel wood species used in the smoking experiment were the neem (Azadirachta indica), desert date (Balanites aegyptiaca), red-flowered silk cotton (Bombax huonopegense), cassia (Cassia siamea), mahogany (khaya senegalensis), raisinier (Lannea acida), leucaena (Leucaena glauca) 
mango (Mangifera indica), teak (Tectona gradis) and the male shea tree (Terminalia absonoides), (Table 1).

This aspect of the results indicate the wide variety of fuel wood species from which fishmongers (smokers) have to choose.

The results (Table 2) indicate that neem had the highest fuel wood performance $(10.88 \%)$, followed by rainier and leucaena with $10.00 \%$ each. The respective fuel wood efficiency of mango, red-flowered silk cotton and desert date were $9.66 \%, 9.58 \%$ and $8.62 \%$. The fuel wood performance of terminalia was $6.92 \%$; that of mahogany was $6.88 \%$, while cassia had $6.75 \%$. The fuel wood with the lowest fuel wood performance was teak, which recorded $5.71 \%$. The differences in the fuel wood efficiency values of the various firewood species were not significant $(\mathrm{p}>0.05)$.

The high efficiency of the ten fuel wood species used could perhaps be attributed to retention of heat by the oil drum smoker used in the experiment. The good performance of the fuel wood species could also be due to the presence of extractable hexane produced by them. Aronson et al. (1994) reported that good fuel wood produced about 5\% (by weight) of extractable hexane which increased their efficiency of smoking.

Based on the results obtained (Table 3), when each fuel wood was used for smoking, the ten fuel wood species were classified into 'good' or 'bad' fuel wood. The good fuel wood species produced golden brown or dark brown colour, either of which was preferred by consumers. These were mahogany, mango, red-flowered silk cotton and terminalia all of which imparted golden brown colour in smoked fish. The others, which produced dark brown colour, were cassia, leucaena, neem and teak. Two fuel wood species which imparted light brown colours, which consumers did not like, were raisinier and desert date. These were, hence, classified as 'bad' smoking fuel wood species.

The classification of the fuel wood species used in this study into 'good' and 'bad' smoking species was based on the quality (and perhaps quantity) of smoke produced. The good smoking fuel wood species probably produced moderate amount of smoke. Baumer (1974) reported that teak is a good fuel wood, because it generates moderate amount of smoke and high temperature as it burns. Teak was also found to produce dark brown colour (desirable) in the current experiment. Ihekoronye and Ngoddy (1985) asserted that if fish was smoked at too high a temperature, it produced a bitter taste. They therefore concluded that good fuel wood species generated temperatures in moderation. The bad smoking fuel wood species probably generated less amount of smoke of poor quality which could not impart the desirable colours to the smoked fish. Bad smoking fuel wood also produces charred smoked fish (Obodai et al., 2002). However, none of the fuel wood tested produced black colour, because all were popular firewood species within the locality (Nyankpala, Northern Region of Ghana).

According to Martin (1978) the most desirable colours of smoked fish are golden brown and dark brown. This author reported that these colours can be obtained in smoked herrings by eviscerating (gutting) and smoking them for $2 \frac{1}{2}$ hours. Steinberg et al. (1976) claimed that the pacific lake (Merluccius productus) which had been beheaded and muscles separated by mechanical deboning and smoked for only 20 seconds at a temperature of $150^{\circ} \mathrm{C}$, using oil drum smoker, also produced dark brown colour in the smoked fish. Tuna that weighed as heavy as $71 \mathrm{~kg}$ could be smoked for 3 hours in oil drum smoker to obtain dark brown colour in the smoked fish. Maddision et al. (1993) reported that the right type of fuel wood produced golden brown colour in smoked fish. These authors claimed that hard wood and coconut husk used together in smoking produced golden brown colour in smoked fish. The preference for dark brown and golden brown colours by the consumers interviewed in this study is in agreement with the desirable colours referred to by the authors cited above.

It was reported that resinous and Euphorbia fuel wood species produced poisonous smoke and must therefore not be used for fish smoking (Maddison et al.,1993; Brigitte et al., 1994)]. Accordingly, these species were avoided in the choice of the fuel wood species used in the current study. The smoked fish produced were thus safe for human consumption.

The results (Table 4) indicate that 31 species belonging to 21 families were sold on the TCM. These were Phractura clauseni (Amphilidae or loach catfish), Bagrus bajad (Bagridae or bagrids), Lates niloticus (Centropomidae or nile perch), Hydrocynus 
brevis, Brycinus nurse (Characidae or characins), Channa obscura (Channidae, or snakehead), Oreochromis niloticus, Tilapia aurea, T. galilaeus T.zillii (Cichlidae or the cichlids), Citharinus citharus, C. distichoides, Alestes baremoze (Citharinidae or moonfish), Chrysichthys auratus (Claroteidae or claroteids), Clarias gariepinus, Heterobranchus bidorsalis (Claridae or mudfish) Sierranthrissa leonensis (Clupeidae or freshwater herring), Labeo seneglensis, Barbus wurtze, Leptocypris niloticus (Cyprinidae or African carps), Gymnarchus nioticus (Gymnarchidae or frankfish) Hepsetus odoe (Hepsetidae or African pike), Malapterurus electricus (Malapteruridae or the electric fish) Aethriomastacembelus praensis. (Mastacemberlidae or the spiny eels), Synodontis clarias, S. filamentosus (Mochokidae or squeaker catfish), Mormyrus rume (Mormyridae or the elephant nose fish) Heterotis niloticus (Osteoglossidae or Bony tongue fishes), Polyterus senegalensis (Polypteridae, bichirs or sailfish), Protopterus annectens (Protopteridae or African lunfish) and Tetraodon fahaka (Tetraodontidae or the puffer fish).

The high diversity of smoked freshwater fish species observed on the Tamale Central Market has to do with the various sources from where these come. In comparison with the results of an earlier work by Obodai and Laweh (2009) who reported 34 fish species in the White Volta (at Nawuni) alone, the current result suggests that not all fish species caught are smoked for sales on the Tamale Central Market. Indeed, some are processed into Kobi or Momone, either of which lasts longer and serves as condiment (e.g. Maggie cube). These add extra taste and flavour to cooked food. However, the findings show higher fish species diversity than that by Obodai and Kwofie (2001) for the Bontanga Reservoir. The higher fish species diversity could be an index of the relatively large area drained by the water bodies involved in the current study (Rosenzwieg, 2000), compared with the relatively small size of the Bontanga Reservoir.

The result (Table 5) shows that the smoked freshwater fish sold on the TCM came from nine sources, namely Buipe, Daboya, Dalon, Dalon, Dilali, Kudanali, Makango, Nawuni, Yapei (all int eh Northern Region) and Yeji in the Brong Ahafo Region.
The large volume of smoked freshwater fish species flow into the Tamale Central Market is indicative of the ready market (high demand) for the product within the Tamale Metropolis. Generally, fish products are inexpensive and hence affordable by all, irrespective of their financial status. The rather high demand for smoked freshwater fish species on the Tamale Central Market could also be due to the flavour and taste added to the product by the smoking process (Pyke, 1981).

The difference in the quantity of smoked fish supply from the various sources, perhaps, reflects the relative viability of the fishing industry in these areas. For instance, Yeji which had the highest contribution of smoked fish to the Tamale Central Market is known for its vibrant capture fishing activities. Yeji is situated on the bank of the Volta Lake, the largest man-made lake in Africa. The lake is reported to have high diversity of freshwater fish species (about 60 fish species) (Dankwa et al., 1999) due to the large area drained by the lake (Rosenzwieg, 2000).

Table 6 indicates the various sources of fish and the corresponding values purchased per week by the individual fishmongers in the market during the survey. It was observed that fishmongers with serial numbers 8 and 9 in Table 6(a) were those purchasing most of the smoked freshwater fish products valued at GH $₫ 350.00$ each; Mongers 5 and 10 purchased smoked fish valued at $\mathrm{GH} \phi 250.00$ each. Fishmonger 7 was third with $\mathrm{GH} \phi 200.00$. Mongers 3, 2 and 4, followed in that order with their corresponding amounts given in parentheses: (GH $\not 100.00),(\mathrm{GH} \notin 150.00)$ and (150.00). The values of smoked fish purchased by fishmongers 1 and 6 were $\mathrm{GH} \phi 125.00$ and $\mathrm{GH} \not 100.00$, respectively.

Table 7 shows yearly estimated contributions of smoked freshwater fish by the various sources to the TCM. The annual estimate was highest for Yeji, which produced 988 small baskets, costing ( $\mathrm{GH} \phi 49,400.00)$; followed by Buipe and Yapei with 312 baskets which amounted to $\mathrm{GH} \notin 15,600.00$ for each source. Nawuni had 286 baskets valued at $\mathrm{GH} \notin 14,300.00$, Dalon contributed 110 baskets at GH $\varnothing 6,500.00$, Makango, 104 baskets valued at $\mathrm{GH} \varnothing 5,200.00$ and Kudanali recorded the least annual estimate of 78 baskets that sold at $\mathrm{GH} \notin 3,900.00$. Thus smoked freshwater fish contributed a total of $\mathrm{GH} \phi 110,500.00$ to the 
Gross Domestic Product (GPD) of Tamale economy.

The significant contribution of the sources from the Northern Region to the Tamale Central Market is indicative of self-sufficiency in fish production. However, the sustenance of this fish supply could be another problem. Results of some studies indicate that most of the inland water bodies are being overexploited by fishermen who use poisonfishing method as well as undersized net meshes legally prohibited by the Fisheries Department (Obodai and Laweh, 2009). This calls for the need to put in place and enforce appropriate management strategies for sustaining the inland fishing industry. Development of aquaculture in the inland water systems should be encouraged to divert attention from these over-exploited water bodies. One of such moves was the work done

\section{References}

Anazonwu-Bello, J.N. (1976). Food and Nutrition. Macmillan, London. 119 pp.

Aronson, J.L., Tokin, M.S. and Winkler, S. (1984). Agroforestry and Desertification,

ICRAF publications 1990, 119-120.

Baumer, M. (1974). Agroforestry and Desertification., ICRAF publications. 1990, 121-123.

Bender, A.E. (1982) Dictionary of Nutrition and Food Technology. Fifth edition.

Butterworth and G. 308 pp.

Brigitte, M.B., Brigitte, V.B. and Corlein, H. (1994) Preservation of Fish and Meat.

Agrodok Series No.12. Netherlands. 66 pp.

Clucas, I.J. (1982) Fish handling, processing and preservation in tropics. Part 2.

Tropical Products Inst. G145, 144 pp.

Denkwa, H. R., Abban, E. K. and G.G. Teugels (1999) Freshwater Fishes of

Ghana: Identification, Ecological and Economic Importance

Royal Museum for Central Africa, Leuvensesteenweg 283. 53pp

Garrow, J.S. and James, W.P.T. (1994).

Human Nutrition and Dietetics.

Churchill Livingstone, London. 84 pp.

Holden, M. and Reed, W. (1991). West

African Freshwater Fish. Longman Group

Ltd. CTA. 68pp. by Obodai et al. (2002) on integrated poultryfish production in an abandoned burrow pit at Bontanga in the Tolon-Kumbungu District of the Northern Region of Ghana.

\section{Conclusion}

The study had examined the effect of different species of fuel wood on smoked fish in Tamale Central market the findings revealed that eight of the ten fuel wood species tested produced desirable colours, while two imparted undersirable colours in smoked fish. These eight good fuel wood species are therefore recommended for fish smoking.

Thirty-one smoked freshwater fish species, most of which came from Yeji, were sold on the Tamale Central Market. Smoked freshwater fish products make a significant contribution to the economy of the Tamale Metropolis. Freshwater inland fisheries must thus be properly managed for sustainability.

Ihekoronye, A.I., and Ngoddy, P.O. (1985). Integrated Food Science and Technology

for Tropics. MacMillan London. 386 pp.

Maddison, A., Machell, K. and Adams, L. (1993). Fish processing: Food Cycle

Technology Source books, International Technology Publications, London, 66.pp.

Martin, C.R.A. (1978). Practical food inspection. Ninth edition. Hazell Watson and Viney Ltd. Alesbury, $232 \mathrm{pp}$.

Mayhew, S. and Penny, A. (1988). Tropical and subtropical foods. MacMillan,

London. $291 \mathrm{pp}$.

Obodai, E.A. and Kwofie, J.E. (2001). Fish species composition and efficiency of

Selected gill nets used in Bontanga Reservoir. Development Spectrum; an Interfaculty Journal of the Univ. for Dev. Studies, Tamale, Ghana 1, No. 1, 4-10.

Obodai, E.A. and Laweh, M.A. (2009). A survey of fish species diversity and

abundance in the White Volta at Nawuni Northern Region, Ghana. Intl. J. Biol. Chem. Sci. 3(2): 378-385.

Obodai, E.A. and Waltia, S.C. (2003). Preliminary observation on capture fishery activities in the Tono Dam. U-E Region, Ghana Journal of the Ghana Science

Association. 5, No. 2, 1-10. 
Obodai, E.A. Lawson, I.Y.D. and Dei, H.K. (2002) Integrated poultry-fish production in The Tolon-Kumbungu District, Northern Region (Ghana) 31 pp. A Research Report of SADAOC Project No. 10 submitted to SADAOC Ouagadougou,Jan. 2003.

Osuji, F.N.C. (1976) Influence of traditional handling methods on the quality of

Processed fish in Nigeria. Conference on handling, processing and marketing of tropical fish 5-9 $9^{\text {th }}$ July, 1976 London, U.K. 319-322. Paul, W. and Southgate, L. (1978) Fish and meat consumption in the Tropics. MacMillan, London, $287 \mathrm{pp}$.

Paul, W. and Southgate, L. (1978) Fish and meat consumption in the Tropics.

MacMillan, London. 287pp.
Pyke, M. 1981. Success in Nutrition. John Murray Ltd. London.

Robinson, R.K. (1983). The vanishing Harvest: A study of food and its

Conservation. Oxford University Press., New York. 134 pp.

Rosenzwieg, L.M. (2000) Species diversity in space and time. Cambridge

University Press, 436 pp.

Sipe, M. (1993). Tilapia marketing in the U.S.A. Aqua Farm News, XII, No. 3, 1-

Steinberg, M.A., Spinelli, J. and Miyauchi, D. (1976) Minced fish as an ingredient

in food combinations. Conference on handling, processing and marketing of tropical fish. 5-9 ${ }^{\text {th }}$ July, 1976. London, 245248.

Table 1. The ten fuel wood species used in smoking freshwater fish species

\begin{tabular}{llc}
\hline & Common Name & Botanical Name \\
\hline 1 & Neem & Azadirachta indica \\
2 & Desert date & Balanites aegyptiaca \\
3 & Red-flowered silk cotton & Bombax huonopegense \\
4 & Cassia & Cassia siamea \\
5 & Mahogany & Khaya senegalensis \\
6 & Raisinier & Lannea acida \\
7 & Leucaena & Leucaena glauca \\
8 & Mango & Mangifera indica \\
9 & Teak & Tectona gradis \\
10 & Male shea tree & Terminalia absonoides \\
\hline
\end{tabular}


Table 2: Relative efficiency (fuel wood performance) of the ten fuel wood species Used in smoking fish

\begin{tabular}{lc}
\hline Common Name of fuel wood & $\begin{array}{c}\text { Relative fuel wood efficiency (Fuel wood } \\
\text { Performance, FWP, \%) }\end{array}$ \\
\hline Neem & 10.88 \\
Raisiner & 10.00 \\
Leucaena & 10.00 \\
Mango & 9.66 \\
Red-flowered silk cotton & 9.58 \\
Desert date & 8.62 \\
Male shea tree & 6.92 \\
Mahogany & 6.88 \\
Cassia & 6.75 \\
Teak & 5.71 \\
\hline
\end{tabular}

Table 3: Classification of the ten fuel wood species into 'good' and 'bad' fuel wood types

\begin{tabular}{|c|c|c|c|c|}
\hline & \multirow[t]{2}{*}{ Name of fuel wood species } & \multicolumn{3}{|c|}{ Quality of fuel wood } \\
\hline & & & 'Good' & 'Bad' \\
\hline 1 & Mahogany & & GB & - \\
\hline 2 & Mango & & GB & - \\
\hline 3. & Red-flowered silk cotton & GB & & \\
\hline 4 & Terminalia & & GB & - \\
\hline 5 & Cassia & & DB & - \\
\hline 6 & Leucaena & & DB & - \\
\hline 7 & Neem & & DB & - \\
\hline 8 & Teak & & DB & - \\
\hline 9 & Desert date & & - & LB \\
\hline 10 & Raisinier & & - & LB \\
\hline
\end{tabular}

* $\mathrm{GB}=$ Golden Brown; $\mathrm{DB}=$ Dark Brown; $\quad$ LB = Light Brown

Good fuel-wood species produced golden brown or dark brown colour, either of which was preferred. Bad fuelwood species produced light brown colour which consumers did not like. 
Table 4: A checklist of smoked freshwater fish species sold on the Tamale Central Market

\begin{tabular}{|c|c|c|}
\hline Family Name & Scientific name & English/Common Name \\
\hline Amphilidae & Pharactura clauseni & Loach catfish \\
\hline Bagridae & Bagrus bajad & Bagrids \\
\hline Centropomidae & Lates niloticus & Nile perch \\
\hline Characidae & $\begin{array}{l}\text { Hydrocynus brevis } \\
\text { Brycinus nurse }\end{array}$ & Characins \\
\hline Channidae & Channa obscura & $\begin{array}{l}\text { Snakehead } \\
\text { Moonfish }\end{array}$ \\
\hline Cichlidae & $\begin{array}{l}\text { Oreochromis niloticus } \\
\text { Tilapia aurea } \\
\text { T. galilaea } \\
\text { T. zillii }\end{array}$ & Bream/mangofishes \\
\hline Citharinidae & $\begin{array}{l}\text { Citharinus citharus } \\
\text { C. distichodoides } \\
\text { Alestes baremoze }\end{array}$ & Moonfish \\
\hline Claroteidae & Chrysichthys auratus & Claroteids \\
\hline Clariidae & $\begin{array}{l}\text { Clarias gariepinus } \\
\text { Heterobranchus bidorsalis }\end{array}$ & Mudfish \\
\hline Clupeidae & Sierranthrissa leonensis & Freshwater hearing \\
\hline Cyprinidae & $\begin{array}{l}\text { Barbus wurtze } \\
\text { Labeo senegalensis } \\
\text { Leptocypris niloticus }\end{array}$ & African carps \\
\hline Gymnarchidae & Gymnarchus niloticus & Frankfish \\
\hline Hepsetidae & Hepsetus odoe & African pike \\
\hline Malapteruridae & Malapterurus electricus & Electric catfish \\
\hline Mastacembelidae & Aethriomastacembelus praensis & Spiny eels \\
\hline Mochokidae & $\begin{array}{l}\text { Synodontis clarias } \\
\text { S. filamentosus }\end{array}$ & Squeaker catfish \\
\hline Mormyridae & Mormyrus rume & Elephant nose fish \\
\hline Osteoglossidae & Heterotis niloticus & Bony tongues \\
\hline Polyteridae & Polypterus senegalus & Bichirs or sailfins \\
\hline Protopteridae & Protopterus annectens & African lungfish \\
\hline Tetraodontidae & Tetraodon fahaka & Puffers \\
\hline
\end{tabular}

Table 5: Sources of smoked freshwater fish species sold on the Tamale Central Market

\begin{tabular}{lc}
\hline Source & Region \\
\hline Buipe & Northern Region \\
Daboya & Northern Region \\
Dalon & Northern Region \\
Diali & Northern Region \\
Kudanali & Northern Region \\
Makango & Northern Region \\
Nawuni & Northern Region \\
Yapei & Northern Region \\
Yeji & Brong Ahafo Region \\
& \\
\hline
\end{tabular}


Table 6: Smoked freshwater fish species purchased by individual fishmongers

\begin{tabular}{|c|c|c|c|}
\hline Fishmonger & Source of Fish Supply & $\begin{array}{l}\text { Quantity Purchased from } \\
\text { Source Per Week }\end{array}$ & Amount GH $\varnothing$ \\
\hline \multirow[t]{4}{*}{1.} & Dalon & $1 / 2$ small basket & 25.00 \\
\hline & Kudanali & $1 / 2$ small basket & 25.00 \\
\hline & Nawuni & $1 / 2$ small basket & 25.00 \\
\hline & Yeji & 1 small basket & 50.00 \\
\hline \multirow[t]{3}{*}{2.} & Makango & 1 small basket & 50.00 \\
\hline & Nawuni & 1 small basket & 50.00 \\
\hline & Yeji & 1 small basket & 50.00 \\
\hline \multirow[t]{4}{*}{3.} & Dalon & $1 / 2$ small basket & 25.00 \\
\hline & Kudanali & $1 / 2$ small basket & 25.00 \\
\hline & Nawuni & 1 small basket & 50.00 \\
\hline & Yeji & 2 small basket & 80.00 \\
\hline 4. & Yeji & 3 small baskets & 150.00 \\
\hline 5. & Yeji & 5 small baskets & 250.00 \\
\hline \multirow[t]{3}{*}{6.} & Dalon & $1 / 2$ small basket & 25.00 \\
\hline & Kudanali & $1 / 2$ small basket & 25.00 \\
\hline & Nawuni & 1 small basket & 50.00 \\
\hline \multirow[t]{3}{*}{7} & Dalon & 1 small basket & 50.00 \\
\hline & Nawuni & 1 small basket & 50.00 \\
\hline & Yeji & 2 small baskets & 100.00 \\
\hline \multirow[t]{4}{*}{8.} & Buipe & 2 small baskets & 100.00 \\
\hline & Nawuni & 1 small basket & 50.00 \\
\hline & Yapei & 1 small basket & 50.00 \\
\hline & Yeji & 3 small baskets & 150.00 \\
\hline \multirow[t]{4}{*}{9.} & Buipe & 2 small baskets & 100.00 \\
\hline & Makango & 1 small basket & 50.00 \\
\hline & Yapei & 2 small baskets & 100.00 \\
\hline & Yeji & 2 small baskets & 100.00 \\
\hline \multirow[t]{2}{*}{10.} & Buipe & 2 small baskets & 100.00 \\
\hline & Yapei & 3 small baskets & 150.00 \\
\hline
\end{tabular}

Table 7: $\quad$ Supply of smoked freshwater fish species to the TCM by each source in 2003

\begin{tabular}{lcc}
\hline Source & $\begin{array}{c}\text { Quantity of Smoked Fish } \\
(\text { No. of small baskets) }\end{array}$ & $\begin{array}{c}\text { Estimated Cost } \\
(\mathrm{GH} \phi)\end{array}$ \\
\hline Yeji & 988 & $49,400.00$ \\
Buipe & 312 & $15,600.00$ \\
Yapei & 321 & $15,600.00$ \\
Nawuni & 286 & $14,300.00$ \\
Dalon & 110 & $6,500.00$ \\
Makango & 104 & $5,200.00$ \\
Kdanali & 78 & $3,900.00$ \\
\hline Total & $\mathbf{2 , 1 9 0}$ & $\mathbf{1 1 0 , 5 0 0 . 0 0}$ \\
\hline
\end{tabular}

